IPA05-G-045

PROCEEDINGS, INDONESIAN PETROLEUM ASSOCIATION

Thirtieth Annual Convention \& Exhibition, August 2005

\title{
EAST JAVA: CENOZOIC BASINS, VOLCANOES AND ANCIENT BASEMENT
}

\author{
Helen Smyth* \\ Robert Hall* \\ Joseph Hamilton** \\ Pete Kinny***
}

\begin{abstract}
East Java on land is divided here into four broadly EW zones: (1) the Southern Mountains Zone, an Eocene to Miocene volcanic arc, separated by (2) the present-day volcanic arc from (3) the Kendeng Zone which was the main Cenozoic depocentre in onshore East Java; and to the north (4) the Rembang Zone which represents the edge of the Sunda Shelf. Several synthems separated by unconformities can be identified and correlated between the different zones. There is a regional angular unconformity above Upper Cretaceous and older basement. The oldest rocks above the unconformity range from Mid Eocene to Lower Oligocene and record a gradual transgression and, in SE Java, an increase in volcanic material up-section.
\end{abstract}

After an intra-Oligocene sea-level fall, volcanic material from the arc dominated in the Southern Mountains and Kendeng Zones while in the Rembang Zone carbonate deposition continued. In the Early Miocene, activity in the Southern Mountains Volcanic Arc culminated in a major eruptive phase at $20 \mathrm{Ma} \pm$ $1 \mathrm{Ma}$, similar in scale to the Pleistocene eruptions of Toba. To the north carbonate deposition was interrupted by clastic input containing reworked basement and Eocene material. The Mid Miocene was a period of reworking and carbonate sedimentation. In the Late Miocene volcanic activity recommenced at the position of the present-day arc and there was a series of deformation events throughout East Java. Volcanism has played an important role in the development of East Java, providing a source of material and contributing to subsidence by flexural loading. Provenance studies and dating of zircons

\footnotetext{
* SE Asia Research Group, Geology Department, Royal Holloway University of London

** University of the West Indies

*** Curtin University of Technology
}

provide insight into the basement character and suggest that continental crust of Gondwana (possibly Western Australian) origin lies beneath part of the Southern Mountains Zone. It is suggested that continental Sundaland provided very little, if any, terrigenous material to East Java in the Cenozoic.

\section{INTRODUCTION}

Java is located on the SE edge of the Eurasian Plate, at the Sundaland margin. Sundaland is the continental core of SE Asia and is commonly thought to be the main source of sediment to East Java (e.g. Ardhana, 1993; Sribudiyani et al., 2003). To the south of Java, subduction of the Indo-Australia Plate beneath the Eurasian Plate has occurred along the Java Trench (Figure 1) from the Middle Eocene to the present-day (Hall, 2002). As a consequence of subduction since the Early Cenozoic, Java is essentially a volcanic island and contains the products of active and ancient volcanism. The volcanoes of the modern Sunda Arc are distributed along the length of the island and a second older arc of Eocene to Miocene volcanoes forms the Southern Mountains of East Java.

This summary of the onshore geology of East Java reports results from a field-based study including provenance and geochemical work, and $\mathrm{U}-\mathrm{Pb}$ SHRIMP (Sensitive High Resolution IonMicroprobe) dating of zircons. The work was focused largely on examination of basement and Eocene to Miocene rocks exposed at the surface. This paper reports work carried out since that presented in Smyth et al. (2003).

\section{TECTONO-STRATIGRAPHIC ZONES OF EAST JAVA}

The study area in East Java is subdivided into four east-west trending zones (Figure 1) based on the van 
Bemmelen (1949) scheme. The zones are defined by stratigraphy and structure and, from south to north, are:

Southern Mountains Zone: an Eocene-Miocene volcanic arc (named here the Southern Mountains Volcanic Arc) built on Mesozoic basement. Deposits include siliciclastic, volcaniclastic, volcanic and carbonate rocks which generally dip uniformly to the south.

Present-day volcanic arc: active from the Late Miocene.

Kendeng Zone: the main Eocene-Miocene depocentre in East Java contains thick sequences of volcanogenic and pelagic sediments. It is now an east-west trending thrust belt.

Rembang Zone: the Eocene-Pliocene sequence includes shelf-edge deposits such as shallow marine clastic sediments and extensive carbonates. This zone contains one major ENE-WSW fault-bounded high (Rembang High) and many east-west orientated folds.

\section{STRATIGRAPHY}

The Cenozoic rocks (in the Southern Mountains, Kendeng and Rembang Zones can be subdivided into three unconformity bounded synthems (Figures 2 and $3)$. All were deposited above a poorly dated angular unconformity.

\section{Southern Mountains Zone}

\section{a. Basement}

Basement rocks of Cretaceous age (Hamilton, 1979; Wakita, 2000; Wakita and Munasri, 1994) are restricted to the western part of the study area in the Karangsambung Basement Complex and the Jiwo Hills (Figure 1). These exposures consist of slivers of arc and ophiolitic-type lithologies. There are no basement rocks of continental-type exposed in East Java.

\section{b. Synthem One}

Sedimentation commenced in the Early Cenozoic above an angular unconformity with the deposition of poorly-dated basement-derived fluvial conglomerates. Volcanic material is absent in these basal conglomerates and sandstones. Overlying them is a transgressive sequence of coals, conglomerates, silts and quartz-rich sands of the Nanggulan Formation, dated as Middle Eocene (Lelono, 2000). The sandstones contain volcanic ash layers, pumice and interbeds of tuffaceous mudstone. Higher in the succession nummulitic shoals mark the onset of marine deposition, and the sandstones become increasingly feldspar-rich. Increasing water depth is indicated by volcanogenic turbidites with a diverse planktonic foraminifera assemblage. In this synthem volcanic material increases in abundance up-section as the proportion of basement material decreases, and the sediments change in composition from quartz-rich to feldspar-rich. The sediments of Synthem One are approximately $1000 \mathrm{~m}$ thick but are exposed only in the western part of the study area (Karangsambung, Nanggulan and Jiwo).

This synthem also contains the enigmatic Jatibungkus Limestone at Karangsambung and the Pendul Slump Member of the Wungkal-Gamping Formation in the Jiwo Hills. The Jatibungkus Limestone is a block of Upper Paleocene limestone within volcanogenic turbidites of the Banjarsari Member of the Karangsambung Formation. Previous workers have suggested that the Jatibungkus Limestone is an olistolith and forms part of an olistostrome (e.g. Lunt et al., 1998; Paltrinieri et al., 1976) for which they have implied a tectonic origin. Paltrinieri et al. (1976) explicitly suggested that "rocks of different age were mixed and tectonically deformed within a clay matrix" in a "paroxysmal phase... .... at the end of the Eocene". As the block is suspended within a matrix of andesitic sandstones, which form part of a continuous sequence of turbidites, we suggest that the limestone block was dislodged, transported and redeposited by a lahar or volcanic landslide. The Pendul Slump Member is an unusual mixture of schist fragments, Nummulites tests, lithic clasts of nummulitic limestone, and mud. As the mud is rich in finegrained volcanic material and there is abundant volcanic debris in other sequences of this age, we suggest that the member is the product of slumping of over-steepened volcanic ash accumulations which formed lahars in a terrestrial setting. The lahars picked up schist fragments from a fluvial channel, then moved into the sea picking up Nummulites and limestone from the seabed, redepositing the material in a marine setting. 
The upper boundary of this synthem is an intraOligocene unconformity, interpreted here to be the result of sea level change, as the sediments immediately above and below the gap have similar bedding orientations, with no indication of deformation.

\section{c. Synthem Two}

The Oligo-Miocene deposits of Synthem Two are primary volcanic deposits that cover the entire Southern Mountains Zone. They record the development and termination of the Southern Mountains Volcanic Arc. Volcanic activity was extensive, explosive and of Plinian-type. The deposits range from andesite to rhyolite in composition and include thick ashes, crystal-rich tuffs, pumice-lithic breccias, monomict andesitic breccias, lava domes and lava flows. No basement-derived sediments have been identified in this succession. The thickness of these proximal volcanic deposits ranges from $250 \mathrm{~m}$ to more than $2000 \mathrm{~m}$. The volcanic centres formed an east-west-trending chain of islands (Figure 1). This synthem and the volcanic activity which it records was terminated by a short-lived volcanic event which may have been a super-eruption (discussed below).

\section{d. Synthem Three}

Synthem Three records a period of much-reduced volcanism characterised by erosion and redeposition of the volcanics of Synthem Two and the development of extensive carbonate platforms. These deposits are at least $500 \mathrm{~m}$ thick and built out as aprons into the Indian Ocean or into sub-basins such as the Wonosari Trough (Lokier, 2000; Wilson and Lokier, 2002). Reefs developed on fault-bounded highs or in the shelter of largely extinct volcanoes. Towards the top of the synthem are several ash horizons containing zircons with ages between 10 and $12 \mathrm{Ma}$ based on U-Pb SHRIMP dating, that mark resumption of volcanic activity in the Late Miocene, at the position of the present Sunda Arc. There are also numerous Cenozoic igneous intrusions in this zone.

\section{Kendeng Zone}

The Kendeng Zone contains more than $8000 \mathrm{~m}$ of sediment (de Genevraye and Samuel, 1972). Today this depocentre is inverted and its northern part is a major fold-thrust belt which has little surface expression. Interpretation in this zone is hampered by poor exposure and the limited quality and quantity of seismic data.

\section{a. Synthem One}

Sediments of this synthem are not exposed but have been brought to the surface by a number of mud volcanoes. The fragments described are "fine calcareous sandstone and conglomerate bearing Nummulites" (de Genevraye and Samuel, 1972) and are similar in character to Synthem One exposed in the Southern Mountains Zone.

\section{b. Synthems Two and Three}

Synthems Two and Three are represented by thick successions of interbedded volcaniclastic sandstones and pelagic mudstones. The sandstones formed in volcaniclastic aprons on the southern margins of the depocentre and pass northwards into finer-grained pelagic sediments. Although deposited in the deeper parts of the basin, the mudstones still contain significant proportions of volcanogenic clays. In the northwestern part of the Kendeng Zone are the Lutut Beds (van Bemmelen, 1949; Lunt et al., 2000) which are unusual in being quartz-rich and containing clasts of basement (e.g. chert, schist and basalt), clasts of Eocene quartzose sandstones, as well as contemporaneous volcaniclastic material. The area of exposure is small but the presence of basement and Eocene clasts suggests uplift and erosion during the Early Miocene. The sediments of Synthems Two and Three were derived primarily from the Southern Mountains Volcanic Arc. The timing of deformation and uplift that generated the Kendeng Fold-Thrust belt is not certain but it is interpreted by many workers to be Pliocene (e.g. de Genevraye and Samuel, 1972).

\section{Rembang Zone}

As the exposure is so poor in the Rembang Zone the description that follows is based mainly on published reports which used sub-surface data (Kadar et al., 1992; Kadar and Sudijono, 1984; Nawawi et al., 1996; Sharaf et al., 2005) and limited surface sampling during this study. 


\section{a. Synthem One}

The oldest sediments within the Rembang Zone, the Pre-Ngimbang Formation, are little studied and their distribution, character, age and source are not well known (Ebanks and Cook, 1993). The Ngimbang Formation records a transgression with a passage from terrestrial sands, through shallow marine limestones to deep marine shales (Ebanks and Cook, 1993). The sands are quartz-rich and are reported to have a local continental source (Sribudiyani et al., 2003). This transgressive sequence is terminated by an intra-Oligocene unconformity and overlain by carbonates of the Kujung Formation. The beds above and below the gap have similar bedding orientations, suggesting that eustatic sea level fall, rather than a deformation event, caused the break in sedimentation.

\section{b. Synthem Two}

Synthem Two in the Rembang Zone is dominated by extensive carbonates of the Kujung and Prupuh Formations. The reduced clastic input is a result of either rising sea level or reduction of relief in the source area. The Oligo-Miocene carbonates contain several ash beds, a product of air-fall from the Southern Mountains Volcanic Arc.

\section{c. Synthem Three}

The Early Miocene was a period when there was a major change in sedimentation. Overlying the thick carbonates of the Kujung Formation, and above a second unconformity, is a series of siliciclastic and carbonate rocks. The clean carbonates of the Kujung Formation (Sharaf et al., 2005) pass up into the terrigenous sediments of the Tuban and Ngrayong Formations (Ardhana et al., 1993). The Ngrayong Formation is a sequence of terrestrial to marginal marine sediments, composed almost entirely of unusual quartz-rich sands which have an uncertain provenance. Several thin $(\sim 10 \mathrm{~cm})$ mantling ash beds suggests that there was some volcanic activity during sedimentation.

\section{VOLCANIC ACTIVITY IN EAST JAVA}

\section{Initiation of arc volcanism in the Southern Mountains}

There is no evidence of arc volcanism in East Java prior to the Middle Eocene. For example, volcanic material is absent from the terrestrial conglomerates at the base of the Cenozoic section, which predate the
Middle Eocene. However, well dated Middle Eocene sediments of the Nanggulan Formation (Lelono, 2000) which immediately overly these rocks contain ash layers and pumice. Indeed, volcanic material is present in all of the younger sequences on land in East Java.

U-Pb SHRIMP dating of zircons separated from sedimentary and volcanic rocks has been used in this study to identify the timing of volcanic activity in the Southern Mountains Arc. The ages range from the Middle Eocene to the Early Miocene (42 Ma to 19-18 Ma). Zircons from the quartz-rich Kali Songo Member of the Nanggulan Formation near Yogyakarta yielded a U-Pb SHRIMP age of $42 \mathrm{Ma} \pm$ 1. This is consistent with biostratigraphic dating of the formation as NP16 or 42.6-39.6 Ma (P. Lunt, pers. comm. 2003) and indicates that volcanic activity was contemporaneous with the deposition of these sediments.

\section{Middle Eocene-Early Miocene Volcanism}

Following the initiation of volcanic activity in the Middle Eocene the volcanic arc grew in size and the contribution of volcanic material to the sediments of East Java increased rapidly. The oldest volcanic deposits of Middle Eocene to Early Oligocene age are exposed only in the Nanggulan and Karangsambung areas and are dominated by thick sequences (at least $500 \mathrm{~m}$ ) of andesitic volcaniclastic sands, volcanogenic muds and thin (decimetres) dacitic ashes. The limited exposure means the location of the volcanic centres cannot be identified although several authors (e.g. Soeria-Atmadja et al., 1994; Sribudiyani et al., 2003) have speculated on its position. The record of Late Oligocene-Early Miocene arc activity is much more complete and volcanic centres define an east-west trending arc of at least 13 mature volcanoes (Figure 1). Volcanism was explosive and of Pliniantype and eruptions distributed material across the Southern Mountains and Kendeng Zones; ash which fell as air-fall deposits in the Rembang Zone is now found as volcanogenic clays in carbonates. In the Early Miocene, activity in the Southern Mountains Volcanic Arc culminated in an intense explosive phase.

\section{Semilir Super-eruption}

The Batu Agung Escarpment contains a well-exposed $2000 \mathrm{~m}$ sequence of volcanic and volcaniclastic 
rocks. The Semilir and Nglanggran Formations form part of this sequence and are exposed over a large area. The Semilir Formation is a thick accumulation of dacitic air-fall, pyroclastic surge and flow deposits produced by an explosive eruption, and the Nglanggran Formation is a series of andesitic volcanic breccias generated by sector or caldera collapse. Detailed field observations indicate that there is no significant break within or between the two formations; this suggests that these deposits may be the product of one eruptive phase. Since the reconnaissance U-Pb SHRIMP dating reported in Smyth et al. (2003), five additional samples were analysed from the top, middle and base of the Semilir Formation in order to constrain the ages of the unit. All of the ages obtained are between 19 and 20 Ma. Unfortunately the Nglanggran Formation did not yield sufficient zircons for SHRIMP analyses, so to constrain the upper age of the formation the detailed biostratigraphic work on the overlying Sambipitu Formation of Kadar (1986) was re-examined (D. Schmidt, 2004, pers. comm.). Near the base of the formation Globigerina binaensis provides a precise age 19-19.8 Ma based on its known first and last occurrence. This date indicates that the entire thickness of the Semilir and Nglanggran Formations was deposited in very short time period, at most about one million years, and possibly much less.

The present-day exposure of the Semilir and Nglanggran Formations covers an area of about 800 $\mathrm{km}^{2}$ and ranges in thickness from $100 \mathrm{~m}$ to greater than $1100 \mathrm{~m}$. The volume of these two formations is estimated to be approximately $300 \mathrm{~km}^{3}$. The thickness and area covered by these deposits in the area of the Batu Agung Escarpment is comparable to that remaining in the Toba area of Sumatra and the character of the deposits have many similarities. Toba erupted 4 times in the Pleistocene between $1.2 \mathrm{Ma}$ and $74 \mathrm{ka}$ (Chesner and Rose, 1991) with the final eruption being the largest known Quaternary eruption. Considering the much greater age of the Semilir deposits, and the effects of compaction and erosion, the character, volume and dating suggest an eruptive record comparable to Toba. The final Toba eruption distributed ash over a huge area from India, the Indian Ocean, the NW Shelf of Australia, and across a large part of SE Asia. If the Semilir event was an eruption on the scale of Toba it may well have been associated with climatic change. Work is in progress to identify deposits of this age offshore and onshore, and estimate the extent and amounts of material produced.

\section{Mid-Late Miocene}

Following the climactic period of intense volcanism in the Early Miocene, volcanic activity was much reduced in the Middle Miocene. The erosion of the now largely extinct arc provided an abundant supply of volcaniclastic material. This volcanic lull was followed by a Late Miocene resumption of vigorous volcanic activity. The axis of the Upper Miocene to present-day arc is some $50 \mathrm{~km}$ to the north of the Southern Mountains Arc. The eruptive products of the Upper Miocene to present-day arc are basic to intermediate with an average $\mathrm{SiO}_{2}$ content of $55 \mathrm{wt} \%$ (Nichols and Whitford, 1979; H, Handley, pers. comm. 2004). In contrast, the products of the Southern Mountains Arc are intermediate to acid with an average $\mathrm{SiO}_{2}$ content of $67 \mathrm{wt} \%$ (this study). The difference could reflect a number of factors including difference in the character of the crust beneath the two arcs, maturity of the arc and the composition of the mantle wedge.

\section{CHARACTER OF THE BASEMENT BENEATH EAST JAVA}

A major objective of this study was to understand the character of the basement beneath East Java. Exposures or occurrences in hydrocarbon wells of Cretaceous basement rocks are restricted to the north and west of the area where they consist of arc and ophiolitic-type lithologies. Elsewhere in East Java the composition of the basement is unknown. Valuable insights into the character and age of the crust beneath East Java came from an unexpected source; from U$\mathrm{Pb}$ SHRIMP dating of zircons separated from sediments, volcanic and intrusive rocks in East Java. The zircon samples yielded a range of ages that extend from the Cenozoic into the Archean (Figure 4C). There are several populations:

Cenozoic: Zircons of Cenozoic age are found in many of the sediments, volcanic and intrusive rocks sampled in East Java and record the activity of the Southern Mountains arc. In some cases the zircon ages indicate that igneous activity was contemporaneous with the deposition of sediments, and in others they indicate that volcanic rocks were reworked into younger sequences.

Cretaceous: The Cretaceous ages are restricted to the north and west of the study area (Figure 4B), a distribution similar to the known occurrences of 
Cretaceous basement, exposed or reported from drilling, such as at Karangsambung and beneath the Rembang High. Several of the samples contain only Cenozoic and Cretaceous ages, and others contain a range of Cambrian-Proterozoic ages in addition to Cretaceous ages. None of the samples that contain Cretaceous zircons has Archean zircons. Possible sources of the Cretaceous zircons are the local basement or a more distant source such as continental rocks of Sundaland. This is discussed in more detail below.

Cambrian-Archean: Many of the samples analysed from the Southern Mountains contain a range of Cambrian to Archean zircons. Those rocks that contain Archean zircons are restricted to the Southern Mountains to the west of Yogyakarta (Figure 4A). None of the rocks exposed or sampled by drilling in the East Java region could have produced these zircons. Their source is discussed below.

\section{Origin of Cambrian-Archean zircons}

The range of zircon ages (Figure 5B) and the presence of Archean ages suggest that magmatic rocks have sampled material of Gondwana origin beneath East Java. However, no rocks exposed, or known from the subsurface, in East Java could provide the age range observed. Either the deep crust includes continental material or sediment subducted beneath East Java has a Gondwana origin. The closest area of continental crust at the surface is in Sundaland, the Mesozoic continental core of SE Asia. Regions which could have provided abundant zircons are granites of SW Kalimantan (Hamilton, 1979), the Malay Peninsula (Liew and Page, 1985), the Malay Tin Belt (Cobbing et al., 1986) and Sumatra (Imtihanah, 2000). None of these are areas are known to contain Archean age material or to be underlain by Archean crust and geochemical evidence suggests basement no older than Proterozoic in areas that have been studied such as the Malay peninsula (e.g. Liew \& Page, 1985). Additional information on the age of the basement in these areas comes from new sediment provenance analyses of Paleogene sediments of northern Borneo which included U-Pb SHRIMP dating of zircons (van Hattum, 2005). These sediments are interpreted to be derived from the erosion of the Schwaner Granites of SW Kalimantan and the Malay Tin Belt (van Hattum, 2005) and do not contain Archean zircons suggesting that there is no Archean crust beneath the Schwaner Mountains of SW Kalimantan or the Malay peninsula. Therefore a more distant source must be sought and the most obvious region is Australia. The basement of northern and western Australia includes Phanerozoic, Proterozoic and Archean rocks. Several recent studies using U-Pb SHRIMP methods (Brugier et al., 1999; Cawood and Nemchin, 2000; Sircombe and Freeman, 1999) have dated zircons from these areas which provide possible source fingerprints. The range identified in the Southern Mountains is very similar to the range of ages from the Perth Basin, Western Australia (Figure $5 \mathrm{~A}$ and B). Zircons from sediments of the Perth Basin have age characteristics which resemble the Yilgarn Blocks (2500-4200 Ma), the Mesoproterozoic and Paleoproterozoic Capricorn (1600-2300 Ma) and Albany-Fraser (1100-1350 Ma) orogenic belts, and the Neoproterozoic Pinjara (500$800 \mathrm{Ma}$ ) orogenic belt (Brugier et al., 1999; Cawood and Nemchin, 2000; Sircombe and Freeman, 1999). Each of these age groups can be identified in the Southern Mountains dataset (Figure 5B). The similarity strongly suggests that the zircons in the Southern Mountains samples have a potential Western Australian provenance or were derived from a continental region that has a similar CambrianArchean history to Western Australia.

We suggest that the most likely explanation for the zircon ages sampled in East Java is that there is a fragment of continental crust of Gondwana affinity and potential Western Australian origin at depth beneath the Southern Mountains. Several fragments rifted off the Australian margin during the Mesozoic in the phase of breakup preceding the separation of India from Gondwana (Müller et al., 2000). An alternative is that sediment eroded from Australia could have been deposited on the Indian Ocean crust and carried beneath Java during subduction. This is much less likely as it would require a fan of sediment extending from Western Australia across the India Ocean covering ocean crust. Such a fan would be larger than the Bengal Fan, there are no major river systems in Australia which could have fed it, and there is no trace of the proximal parts of the fan off Western Australia at present. On the other hand, an Australian crustal fragment could have arrived on the Java margin during the Cretaceous, and possibly even earlier. Collision with the SE margin of Sundaland must have occurred before the Early Cenozoic, as rocks of Middle Eocene age rest above it. 


\section{Basement of East Java}

As discussed in the previous section, the basement of East Java is interpreted to be varied and include metamorphosed terranes of accreted arc and ophiolitic material in the north and west similar to the Karangsambung Basement Complex, and some continental material beneath the Southern Mountains. Four distinct crustal domains have been identified (Figure 4C).

\section{a. Rembang High}

The Rembang High was an elevated region throughout much of the Cenozoic and has a thinner sedimentary cover than the rocks on its flanks. The basement lithologies reported from drilling in this area include ophiolites, metamorphic rocks, and sediments such as chert and sandstone (Nawawi et al., 1996). These rock types are similar to those described from the Meratus Mountains in Kalimantan, interpreted to be an accreted assemblage of Cretaceous arc and ophiolitic terranes (Wakita et al., 1998). It is likely that the basement beneath these two regions is similar.

\section{b. Southern Mountains Zone}

There are several lines of evidence that indicate that there is a continental crust beneath the Southern Mountains, including the long-lived intermediate to acidic arc volcanism, strong positive Bouguer gravity anomaly and the occurrence of Precambrian zircons. This block is bounded to the south by the oceanic crust of the East Java fore-arc basin (Kopp et al., 2001).

\section{c. Kendeng Zone}

The nature of basement within the Kendeng Zone is uncertain as it covered by a thick sedimentary sequence. This zone is noted for its strong negative Bouguer anomaly (Figure 1), which indicates that the basement is deep, and it is suggested to contain more than $8 \mathrm{~km}$ (de Genevraye and Samuel, 1972) to around $11 \mathrm{~km}$ of sediment (Untung and Sato, 1978). This zone must contain the transition or boundary between the different basement types of the Rembang High and the Southern Mountains Zone and therefore may be arc and ophiolitic-type or continental. The present-day volcanic arc is built on part of the Kendeng zone. The average composition of the present-day arc volcanic rocks is significantly more basic than that of the Southern Mountains arc, and at least one of the volcanoes (Ijen) of the present arc $(\mathrm{H}$. Handley, pers. comm., 2004) shows no signs of continental contamination. This suggests the change from continental to arc and ophiolitic-type basement is south of the present arc.

\section{d. Western Block}

The Progo-Muria fault is a significant NE-SW trending structure that marks the abrupt termination of the gravity anomalies of the Kendeng Depocentre and Rembang High (Figure 4C). The crust to the west of this structure, in Central Java, is known to be accreted fragments of arc and ophiolitic terranes such as those exposed within the Karangsambung Basement Complex.

\section{SEDIMENT PROVENANCE}

This study, and an earlier progress report (Smyth et al., 2003), have identified many important characteristics of the sediments of East Java including the presence of material derived from local basement sources, the abundance of volcanic material and the occurrence of volcanic quartz. In addition, U-Pb SHRIMP dating of zircons has shed new light on the origin of the sediments.

\section{Influence of Cenozoic volcanism on sediment character}

The oldest sediments exposed onshore in East Java are the basal conglomerates of the Wungkal-Gamping and Karangsambung Formations, of the Southern Mountains Zone. They are the only sediments on land in East Java that contain no evidence of contemporaneous or reworked arc volcanic material. These terrestrial conglomerates were derived solely from the reworking of local basement, like that exposed at Karangsambung. The absence of volcanic debris is important. The products of arc volcanism are commonly explosive and widespread, but there is no evidence of such material in the basal sediments, and therefore this implies that before the Middle Eocene there was no arc volcanism on land in East Java. As arc volcanism is the result of active subduction, the absence implies that there was no subduction to the south of Java prior to the Middle Eocene. 
Above the basal conglomerates, the new provenance work has indicated that there is a significant, previously unrecognised, volcanic component in all of the sediments on land in East Java. There is a clear trend in the sediments of Synthem One in the Southern Mountains: a significant up-section reduction of basement material in sediments accompanied by an increase in volcanic material (Figure 2). A significant proportion of quartz has a volcanic provenance, which was previously unrecognised (Smyth et al., 2003). This volcanic quartz was concentrated by pyroclastic and subsequent epiclastic processes within the arc, and deposited as air-fall in offshore regions on the shelf. Many of the quartz-rich sands contain volcanic zircons, which have been dated by the U-Pb SHRIMP method and the ages confirm that volcanic activity was contemporaneous with the deposition of these sediments. In addition many of the clay interbeds are rich in smectite, including those within the Ngrayong Formation, and are the product of either the alteration of air-fall deposits or reworking of pre-existing volcanic sequences.

\section{Origin of Cretaceous zircons}

As reported above, many of the samples from the north and west of East Java contain Cretaceous zircons (Figure 4B). These samples include quartzrich sandstones such as the Middle Eocene Lukulo Member, Karangsambung Formation, Nanggulan Formation and the Miocene Ngrayong Formation. There is a widely held belief that these source of these sediments is the continental core of Sundaland (e.g. Ardhana, 1993; Sharaf et al., 2005). This study questions this view.

The Sundaland source regions that may have contributed material to these sands include the Schwaner Mountains, the Malay Peninsula and Sumatra, and submerged parts of the Sunda Shelf, all of which include Cretaceous granites (Cobbing et al., 1986; Hamilton, 1979; Liew and Page, 1985). The closest source region to East Java is the Schwaner Mountains, SW Kalimantan where there are abundant granites. These granites were elevated throughout the Cenozoic and this region provided sediment to northern Borneo (van Hattum, 2005). In order to determine whether the Schwaner Mountains granites were a source of sediment to East Java, the age range of Cretaceous zircons separated from these granites was compared to those obtained from the East Java samples (Figure 5C). The Schwaner Mountains granites have a very narrow range of zircon $\mathrm{U}-\mathrm{Pb}$ SHRIMP ages from 78-89 Ma with a peak around 85 Ma (van Hattum, 2005), but grains of this age range have not been found in East Java. It is therefore unlikely that the Schwaner Mountains contributed sediment to East Java. There are no data on zircons from Sumatra and the Malay Peninsula but since these sources are even further from East Java, we consider them to be even less likely, especially in view of palaeogeographical arguments summarised below.

An alternative source for Cretaceous zircons is the basement rocks similar to those in the north and west parts of East Java such as those exposed at Karangsambung. The basement rocks at Karangsambung did not yield sufficient zircons for U$\mathrm{Pb}$ SHRIMP analyses, so the volcaniclastic rocks which directly overlie the basement were analysed. Assuming zircons in these rocks were derived from a local source their ages will indicate the approximate age range of the underlying basement. The volcaniclastics contained Cretaceous zircons. The age range of Cretaceous zircons from the Karangsambung volcaniclastic rocks were compared to the those of Cretaceous zircons from all other rocks in East Java. The two populations are very similar, in striking contrast to the Schwaner Mountains, and we therefore suggest the Cretaceous zircons were derived from the underlying basement.

\section{Drainage Divide}

The absence of a Sundaland signature in the East Java sediments and in particular the lack of the range of Cretaceous zircons similar to those of the Schwaner Mountains granites, SW Kalimantan, suggests that there was a major barrier or drainage divide between Sundaland and East Java during the Cenozoic. The granites of the Schwaner Mountains supplied material to the sediments of northern Borneo during the Cenozoic, but not to the sediments of East Java. Therefore the barrier must have been situated southeast of the Schwaner Mountains. The Karimunjawa Arch is the most likely position of this drainage divide (Figure 1). This NE-SW trending basement high separates the East and West Java Seas and pre-Tertiary basement rocks are exposed on small islands and on the sea floor at present (Cater, 1981). The arch is reported to have been elevated between most of the period between the Late Eocene and Late 
Miocene (Bishop, 1980) and was a source of sediment for the East and West Java Basins during this time (Cater, 1981; Bishop 1980). To the east of the arch Oligocene-Lower Miocene sediments are marine, but to the west (in the West Java Sea) most of the Lower Miocene and all of the Oligocene sediments are nonmarine (Cater, 1981). A ridge of this size and longevity is likely to have prevented sediment from Sundaland entering the basins of East Java.

\section{CONCLUSIONS}

Volcanic activity commenced in the Southern Mountains volcanic arc during the Middle Eocene and was active until the Early Miocene (from 42 to 18 $\mathrm{Ma})$. There is no evidence of active subduction to the south of Java along the Java Trench prior to the Middle Eocene. Volcanic activity along the Southern Mountains Volcanic Arc was extensive, explosive and of Plinian-type, and the deposits ranged from andesite to rhyolite in composition. From about 18 to $12 \mathrm{Ma}$ there was a lull in volcanic activity, and during the Late Miocene volcanism resumed further north at the position of the present-day volcanic arc. The products of the present-day arc are significantly more basic then the Southern Mountains Volcanic Arc suggesting a non-continental basement beneath the Kendeng Zone.

The Kendeng Depocentre contains in excess of $8 \mathrm{~km}$ of sediment but the gravity data suggest that there is no crustal thinning (C.Ebinger, pers. comm., 2004) This is one of several features which are inconsistent with previous interpretations of this basin as a rift and we suggest that flexural loading of the crust by the chain of volcanoes contributed significantly to subsidence in the Kendeng Zone. This topic requires too much discussion to be dealt with here but the evidence of long-lived volcanic activity, its abundance, and the closely spaced nature of the volcanic centres indicate that volcanic loading must have contributed to subsidence of the region now exposed on land in East Java.

New U-Pb SHRIMP dating of zircon grains indicates that a fragment of continental crust of Gondwana origin, including Archean age material, is located at depth beneath the Southern Mountains volcanic arc. Its most likely origin is from Western Australia. New provenance studies indicate that there were two main sources of sediments in the Cenozoic sequences of East Java: (1) Cretaceous accreted basement similar to that exposed at Karangsambung and Jiwo and (2) the Southern Mountains Volcanic Arc. There is little or no evidence for sediment derived from continental Sundaland. The lack of Sundaland material indicates that there was a significant drainage divide in the Java Sea, probably along the Karimunjawa Arch.

A previously unrecognised, potentially Toba-scale, volcanic episode occurred during the Early Miocene (20 Ma \pm 1 ), the Semilir Super-eruption. This vigorous phase of volcanic activity terminated arc volcanism in the Southern Mountains. Later, the locus of volcanic activity shifted north by about $50 \mathrm{~km}$ to the position of the modern Sunda Arc.

Comparison of the results of this study with published studies dealing with offshore areas to the north in the East Java Sea suggest significant differences between the histories of the two areas. It is important to make a clear distinction in discussion of the East Java region between offshore and onshore. Volcanic material from the Southern Mountains volcanic arc distributed over a large area by explosive volcanic activity could help correlate across much of the region on land and around Java. Precise dating of zircons by SHRIMP would aid in this aim.

\section{ACKNOWLEDGMENTS}

The SE Asia Research Group funded this project. Financial assistance for a number of U-Pb SHRIMP analyses was provided by a grant from the University of London Central Research Fund and by CSIRO, Australia. We are grateful to LIPI for rapid response to fieldwork permission requests and to Dr. Eko Budi Lelono of LEMIGAS who acted as counterpart coordinator. Colin Macpherson and Heather Handley, University of Durham, provided data on the modern volcanic rocks of Java. We thank Peter Lunt for the considerable help with planning, organisation and much fruitful discussion.

\section{REFERENCES}

Ardhana, W., 1993. A Depositional Model for the Early Middle Miocene Ngrayong Formation and Implications for Exploration in the East Java Basin: Indonesian Petroleum Association, Proceedings $22^{\text {nd }}$ Annual Convention, Jakarta, p. 395-443.

Ardhana, W., Lunt, P., and Burgon, G.E., 1993. The deep marine sand facies of the Ngrayong Formation 
in the Turban Block, East Java Basin: In: Atkinson, C.D., Scott, J. \& Young, R. (Eds.) Clastic rocks and reservoirs of Indonesia, IPA Core Workshop Notes, October 1993. Indonesian Petroleum Association, p. 117-175.

Bishop, W. P. 1980. Structure, stratigraphy and hydrocarbons offshore southern Kalimantan, Indonesia. American Association of Petroleum Geologists Bulletin, 64, p. 37-58.

Brugier, O., Bosch, D., Pidgeon, R.T., Byrne, D.I., and Harris, L.B., 1999. U-Pb chronology of the Northampton Complex Western Australia - evidence for Grenvillian sedimentation, metamorphism and deformation and geodynamic implications: Contributions to Mineralogy and Petrology, 136, p. 258-272.

Cater, M.C., 1981. Stratigraphy of the offshore area South of Kalimantan, Indonesia: Indonesian Petroleum Association, Proceedings 10th Annual Convention, p. 269-284.

Cawood, P.A., and Nemchin, A.A., 2000. Provenance record of a rift basin: $\mathrm{U} / \mathrm{Pb}$ ages of detrital zircons from the Perth Basin, Western Australia: Sedimentary Geology, 134, p. 209-234.

Chesner, C.A., and Rose, W.I., 1991. Stratigraphy of the Toba tuffs and the evolution of the Toba caldera complex, Sumatra, Indonesia: Bulletin of Volcanology, 53, p. 343-356.

Cobbing, E.J., Mallick, D.I.J., Pitfield, P.E.J., and Teoh, L.H., 1986. The granites of the Southeast Asian tin belt: Journal of the Geological Society of London, 143, p. 537-550.

de Genevraye, P., and Samuel, L., 1972. The geology of Kendeng Zone (East Java): Indonesian Petroleum Association, Proceedings $1^{\text {st }}$ Annual Convention, p. 17-30.

Ebanks, W.J.J., and Cook, C.B.P., 1993. Sedimentology and reservoir properties of Eocene Ngimbang clastics sandstones in cores of the Pagerungan-5 well, Pagerungan Field, East Java Sea, Indonesia.: In: Atkinson, C.D., Scott, J. and Young, R. (Eds.) Clastic rocks and reservoirs of Indonesia,. IPA Core Workshop Notes, October 1993. Indonesian Petroleum Association, p. 9-36.
Hall, R., 2002. Cenozoic geological and plate tectonic evolution of SE Asia and the SW Pacific: computerbased reconstructions, model and animations: Journal of Asian Earth Sciences, 20, p. 353-434.

Hamilton, W., 1979. Tectonics of the Indonesian region: U.S.G.S. Prof. Paper, 1078, 345pp.

Imtihanah, 2000. Isotopic Dating of the Sumatran Fault System. MPhil Thesis, University of London. 150pp.

Kadar, D. 1986. Neogene Planktonic Biostratigraphy of the South Central Java Area, Indonesia: Geological Research and Development Centre, Bandung. Special Publication, 5, 83pp.

Kadar, D., and Sudijono, 1984. Geological Map of the Rembang Quadrangle, Java. Bandung, Geological Research and Development Centre.

Kadar, D., Subandriyo, D.A., Aziz, F., Suminto, Baharuddin, and Musliki, S., 1992. Excursion Guide Book, Package A: Rembang and Kendeng Zones. Indonesian Petroleum Association.

Kopp, H., Flueh, E.R., Klaeschen, D., Bialas, J., and Reichert, C., 2001. Crustal Structure of the Central Sunda Margin at the Onset of Oblique Subduction: Geophysical Journal International, 147, p. 449-474.

Lelono, E.B., 2000. Palynological Study of the Eocene Nanggulan Formation Central Java Indonesia. PhD Thesis, University of London, 453 pp.

Liew, T.C., and Page, R.W., 1985. U-Pb Zircon Dating of Granitoid Plutons from the West Coast of Peninsular Malaysia: Journal of the Geological Society of London, 142, p. 515-526.

Lokier, S.W., 2000. The Miocene Wonosari Formation, Java Indonesia: Volcaniclastic Influences on Carbonate Platform Development. PhD Thesis, University of London, 648 pp.

Lunt, P., Netherwood, R., and Huffman, O.F., 1998. IPA field trip to Central Java. Indonesian Petroleum Association.

Lunt, P., Sugiatno, H. and Allan, T. 2000. A Review of the Lutut Member in the Type Area, North 
Central Java, Unpublished report, http://nummulites. net/Books/Lutut.pdf.

Matthews, S.J., and Bransden, P.J.E., 1995. Late Cretaceous and Cenozoic Tectono-stratigraphic Development of the East Java Sea Basin, Indonesia: Marine and Petroleum Geology, 12, p. 499-510.

Müller, R.D., Gaina, C., and Clark, S., 2000. Seafloor Spreading Around Australia. In: Veevers, J.J., ed., Billion-year Earth History of Australia and Neighbours in Gondwanaland: Sydney, GEMOC Press, p. 18-28.

Nawawi, A., Suseno, A., and Heriyanto, A., 1996. East Java Basins. Pertamina BPPKA, 107 pp.

Nicholls, I. A. and Whitford, D. J. 1976. Primary Magmas Associated with Quaternary Volcanism in the Western Sunda arc, Indonesia. In: Johnson, R.W. (Ed.) Volcanism in Australasia, Elsevier, 77-90.

Paltrinieri, F., Sajekti, S., and Suminta, 1976. Biostratigraphy of the Jatibungkus section (Lokulo Area) in Central Java: Indonesian Petroleum Association, Proceedings $5^{\text {th }}$ Annual Convention Jakarta, p. 195-204.

Phillips, T.L., Noble, R.A., and Sinartio, F.F., 1991. Origin of hydrocarbons, Kangean Block Northern Platform, offshore northeast Java Sea: Indonesian Petroleum Association, Proceedings $20^{\text {th }}$ Annual Convention, Jakarta, p. 637-662.

Sharaf, E., Simo, J.A., Carroll, A.R., and Shields, M., 2005. Stratigraphic evolution of Oligocene Miocene carbonates and siliciclastics, East Java basin, Indonesia. American Association of Petroleum Geologists Bulletin, v. 89, p. 799-819.

Sircombe, K.N., and Freeman, M.J., 1999. Provenance of detrital zircons on the Western Australian coastline-Implications for the geological history of the Perth basin and denudation of the Yilgarn craton. Geology, 27, p. 879-882.

Smyth, H., Hall, R., Hamilton, J., and Kinny, P., 2003. Volcanic origin of quartz-rich sediments in East Java, Indonesian Petroleum Association, Proceedings $29^{\text {th }}$ Annual Convention Jakarta, p. 541-559.
Soeria-Atmadja, R., Maury, R.C., Bellon, H., Pringgoprawiro, H., Polvé, M., and Priadi, B., 1994. Tertiary magmatic belts in Java: Journal of Southeast Asian Earth Sciences, 9, p. 13-17.

Sribudiyani, M., N., Ryacudu, R., Kunto, T., Astono, P., Prasetya, I., Sapiie, B., Asikin, S., Harsolumakso, A.H., and Yulianto, I., 2003. The Collision of the East Java Microplate and Its Implications for Hydrocarbon Occurrences in the East Java Basin, Indonesian Petroleum Association, Proceedings $29^{\text {th }}$ Annual Convention, p. 335-346.

Untung, M., and Sato, Y., 1978. Gravity and Geological Studies in Java, Indonesia: Geological Survey of Indonesia and Geological Survey of Japan, Special Publication, 6, 207 pp.

van Bemmelen, R.W., 1949. The Geology of Indonesia. Govt. Printing Office, Nijhoff, The Hague, $732 \mathrm{pp}$.

van Hattum, M., 2005. Provenance of Cenozoic Sedimentary Rocks in Northern Borneo. PhD Thesis, University of London, 467 pp.

Wakita, K., 2000. Cretaceous Accretionary Collision Complexes in Central Indonesia: Journal of Asian Earth Sciences, 18, p. 739-749.

Wakita, K., Miyazaki, K., Zulkarnain, I., Sopaheluwakan, J., and Sanyoto, P., 1998. Tectonic Implications of new age data for the Meratus Complex of South Kalimantan, Indonesia: The Island Arc, 7, p. 202-222.

Wakita, K., and Munasri, B., W., 1994. Cretaceous Radiolarians from the Luk-Ulo Melange Complex in the Karangsambung area, Central Java, Indonesia: Journal of Southeast Asian Earth Sciences, 9, p. 2943.

Wilson, M.E.J., and Lokier, S.W., 2002. Siliciclastic and Volcaniclastic Influences on Equatorial Carbonates: Insights from the Neogene of Indonesia: Sedimentology, 49, p. 583-601. 

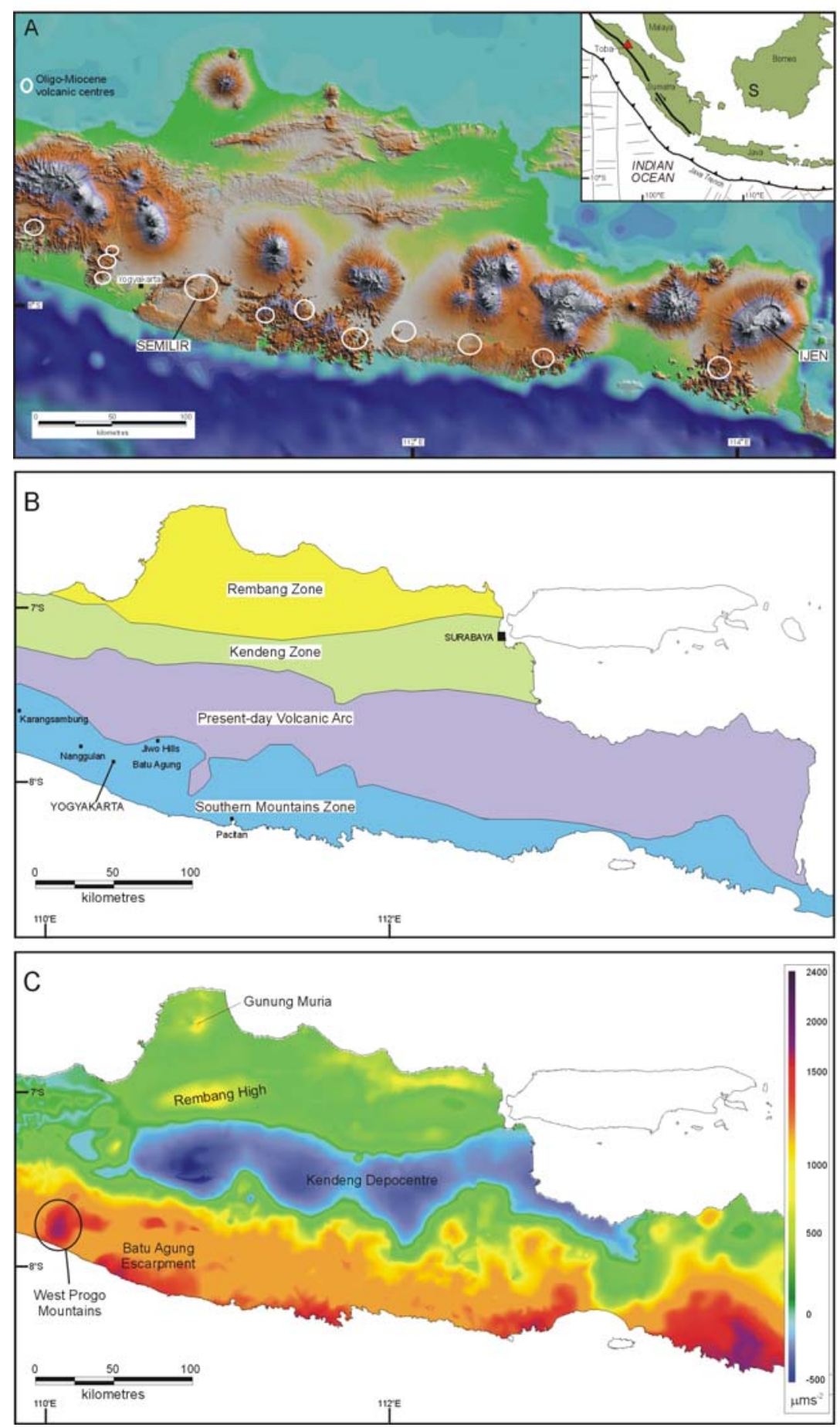

Figure 1 - Location, zones and gravity character of the study area.

A. SRTM digital elevation model of East Java with the centres of Oligo-Miocene volcanism. Inset shows present-day plate tectonic setting (S marks the location of the Schwaner Mountains).

B. East-west trending stratigraphic and structural zones of East Java based on van Bemmelen (1949).

C. Bouguer Gravity Anomaly map of East Java (based on Bouguer Anomaly Quadrangle Maps of Java at 1:100,000 scale, produced by the Geological Research and Development Centre, Bandung) 

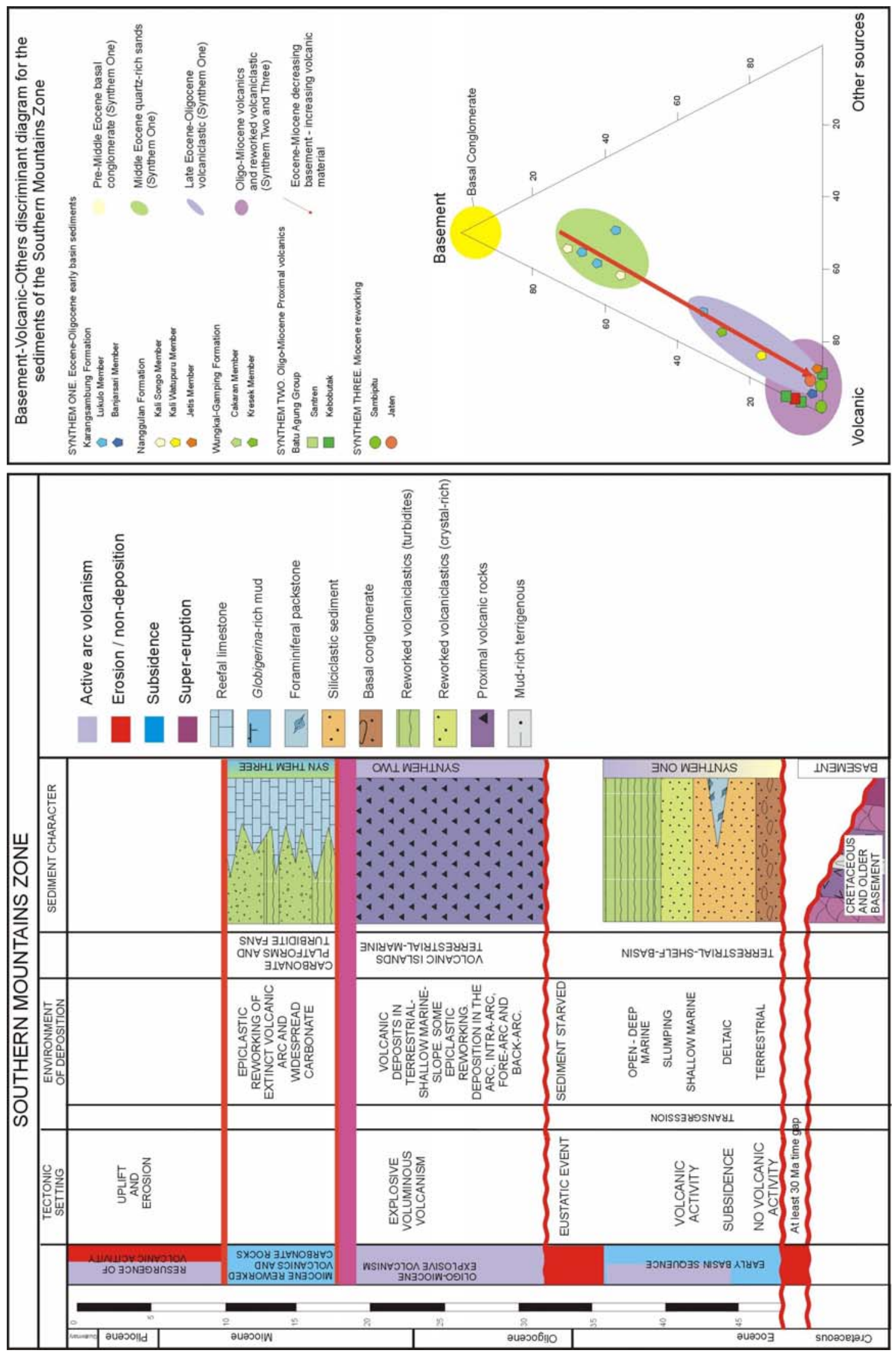

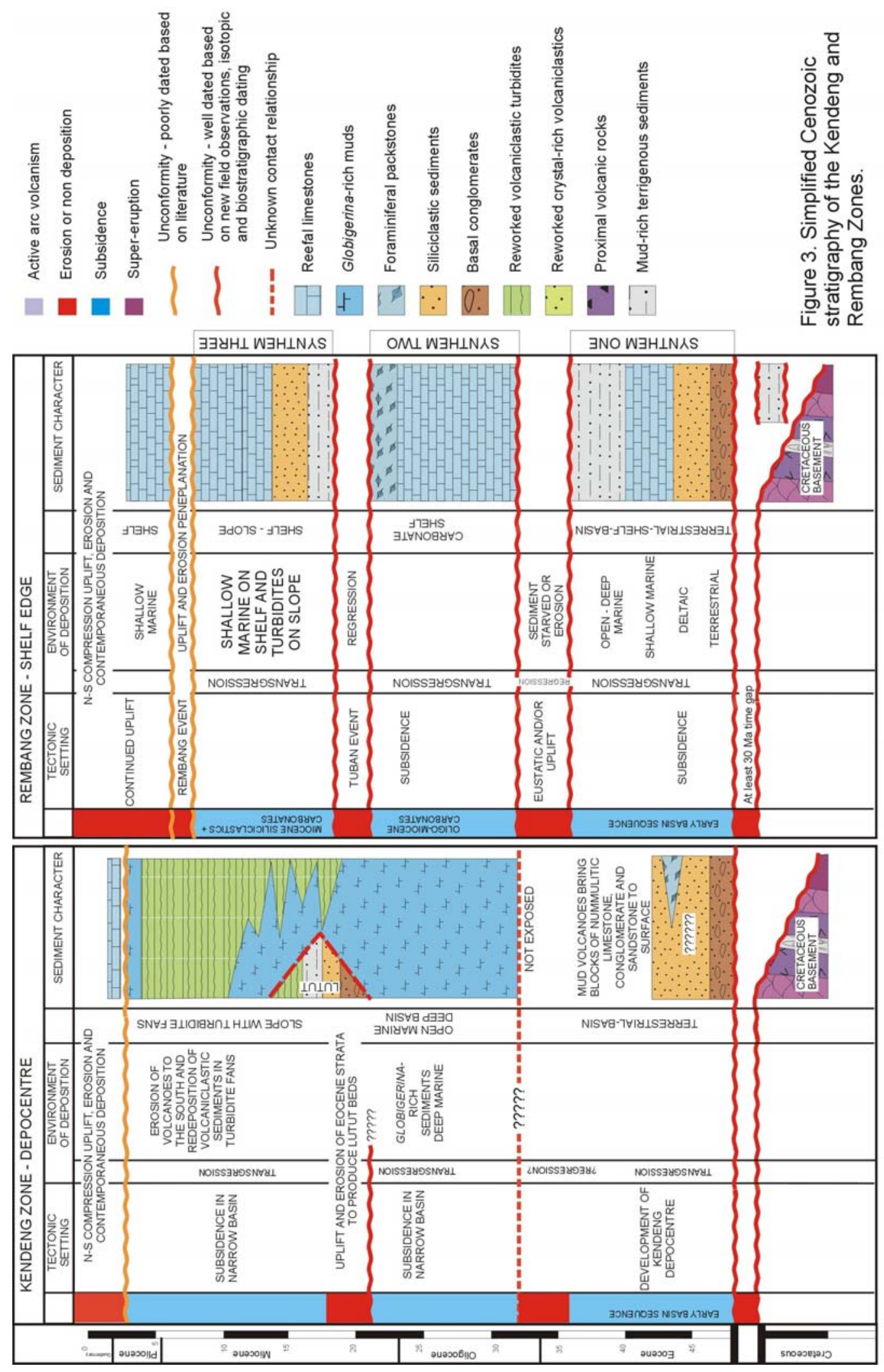

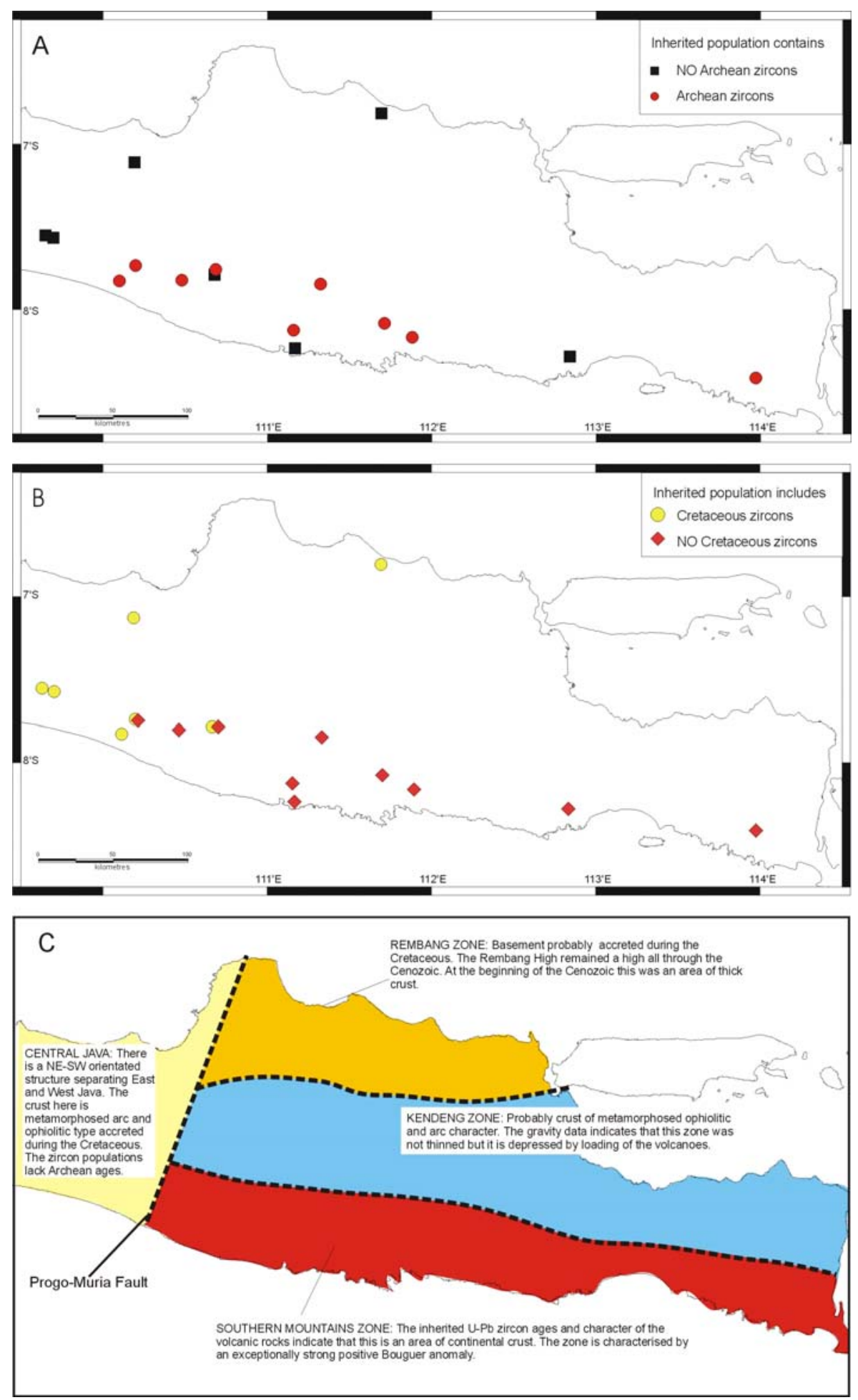

Figure 4 - Details of the zircon U-Pb SHRIMP analyses and interpretation of basement terranes.

A. Distribution of samples with and without Archean zircons. The Archean ages are restricted to the Southern Mountains Zone.

B. Distribution of samples with and without Cretaceous zircons. The Cretaceous zircons are restricted to the western part of the Southern Mountains Zone.

C. Inferred character of the crust beneath East Java. 

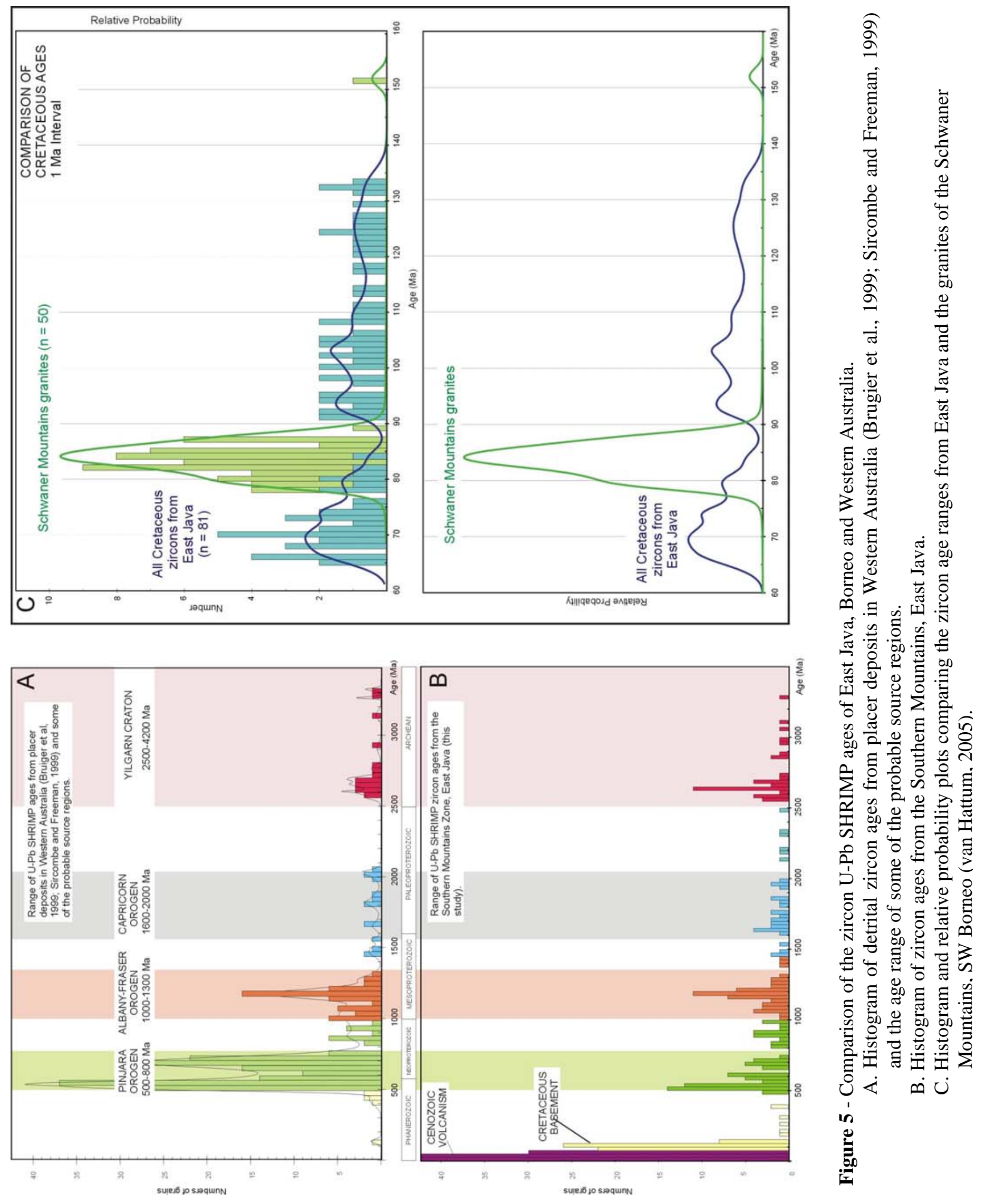